Mutat Res. 2012 May 1; 733(0): 78-82. doi:10.1016/j.mrfmmm.2011.12.002.

\title{
Chromium and Genomic Stability
}

\author{
Sandra S. Wise and John Pierce Wise Sr. ${ }^{* \star}$ \\ Wise Laboratory of Environmental and Genetic Toxicology, Maine Center for Toxicology and \\ Environmental Health, and Department of Applied Medical Sciences, University of Southern \\ Maine, 96 Falmouth St., Portland, ME 04104
}

\section{Abstract}

Many metals serve as micronutrients which protect against genomic instability. Chromium is most abundant in its trivalent and hexavalent forms. Trivalent chromium has historically been considered an essential element, though recent data indicate that while it can have pharmacological effects and value, it is not essential. There are no data indicating that trivalent chromium promotes genomic stability and, instead may promote genomic instability. Hexavalent chromium is widely accepted as highly toxic and carcinogenic with no nutritional value. Recent data indicate that it causes genomic instability and also has no role in promoting genomic stability.

\section{Keywords}

chromium; chromate; trivalent chromium; hexavalent chromium; genomic instability

\section{Introduction}

Genome instability is a key characteristic of most forms of cancer [1]. In the majority of cancers, the integrity of chromosome structure and number is compromised [2]. Genomic instability refers to a large range of genomic changes; numerical and structural chromosome abnormalities are generally referred to as chromosome instability (CIN) and events causing replication slippage or impaired mismatch repair which lead to microsatellite instability (MIN). While the link between genomic instability and cancer is well established, the molecular events leading to genomic instability are not.

In recent years, trace elements have become of significant interest in the prevention of cancer and are thought to have a significant role in the maintenance of the genome [3-6]. Trace elements, those in which less than $100 \mathrm{mg}$ is required daily [6], can have major impacts on the genome when present in excess or when deficient. Of particular concern are metals. Excess metal ions can cause oxidative stress and contribute to the presence of free

\footnotetext{
(C) 2011 Elsevier B.V. All rights reserved.

${ }^{* *}$ Corresponding author: Dr. John Pierce Wise, Sr., University of Southern Maine, 96 Falmouth St. PO Box 4000, Portland, ME 04104, John.Wise@ maine.edu, Phone: (207) 228-8050,FAX: (207) 228-8057.

Publisher's Disclaimer: This is a PDF file of an unedited manuscript that has been accepted for publication. As a service to our customers we are providing this early version of the manuscript. The manuscript will undergo copyediting, typesetting, and review of the resulting proof before it is published in its final citable form. Please note that during the production process errors may be discovered which could affect the content, and all legal disclaimers that apply to the journal pertain.
} 
radicals; however, many of them are required for the normal function and stability of the cellular environment including the detoxification of radicals. Thus, for most metals, it is important to establish a balance for optimum function to maintain cellular and genomic stability.

Metals such as copper, magnesium and zinc are essential to genome stability and play roles as antioxidant and free radical scavenging agents as well as aiding in DNA synthesis and repair processes [4-6]. Copper serves as a co-factor in sodium oxide dismutatse (SOD), thionein and ceruloplasmin, important antioxidants and radical scavengers [5]. Magnesium is involved in almost all DNA processing events including several forms of DNA repair [4]. Levels of zinc have been shown to be related to such things as redox activity, DNA repair activity and chemically-induced carcinogenesis [6].

Chromium is an element which has been a significant concern in the last few decades given its carcinogenicity and its common occurrence. It is a naturally occurring transition metal most commonly found in the oxidation states $\mathrm{Cr}(\mathrm{III})$ and $\mathrm{Cr}(\mathrm{VI})$ [7]. The biochemistry of chromium is very complex and contributes to its reactivity and availability in biological systems. In biological systems, $\mathrm{Cr}(\mathrm{VI})$ is found as the anion, chromate, which is similar to sulfate and phosphate and is readily transported across the cell membrane [8]. Alternatively, trivalent chromium ( $\mathrm{Cr}(\mathrm{III})$ ) forms large bulky molecules such as ternary complexes with amino acids and proteins in biological systems which are poorly absorbed by cells [9]. $\mathrm{Cr}(\mathrm{VI})$ is considered the most potent form of chromium with regards to toxicity and carcinogenicity. $\mathrm{Cr}(\mathrm{VI})$ does not directly interact with DNA, rather it is the intracellular reduction of $\mathrm{Cr}(\mathrm{VI})$ to $\mathrm{Cr}(\mathrm{III})$ which ultimately interacts with and causes the DNA damaging events leading to neoplastic transformation of cells and ultimately cancer [10].

\section{Chromium (III)}

Trivalent chromium has historically been considered an essential trace element. Initial studies, performed in the 1950's suggested a glucose tolerance factor (GTF) containing chromium as the active component, however, subsequent studies have failed to fully isolate and characterize a GTF containing chromium and multiple studies have failed to reproduce the original study $[11,12]$. A handful of studies have been reported on patients receiving total parenteral nutrition (TPN) and lead to the adoption of chromium as an essential nutrient. To summarize, patients on TPN developed symptoms of glucose intolerance which when given $\mathrm{Cr}$ supplementation, were reversed. However, flaws in these studies including $\mathrm{Cr}$ contamination in TPN solution, lack of data regarding serum levels of $\mathrm{Cr}$ before or after supplementation, inconsistent times on non-supplemented TPN between patients, and large variation in onset of symptoms, in addition to small sample size of unhealthy patients, probably lead to an over interpretation of the contribution of $\mathrm{Cr}[12,13]$. In addition, prior to 1980, accurate measurements of chromium in biological material were not valid due to poor detection methods [11]. To date there is no clinically described chromium deficient disease state for humans and research in the area of chromium essentiality is still widely debated $[13,14]$. 
Although the essentiality of $\mathrm{Cr}$ as a nutrient is now in doubt, evidence does show that $\mathrm{Cr}$ can have a therapeutic or pharmacologic effect in certain clinical populations. A meta-analysis of $41 \mathrm{Cr}$ supplementation studies suggested that supplementation specifically benefitted patients with diabetes [15]. One study observed that $\mathrm{Cr}$ supplementation in individuals with type 2 diabetes had inconsistent effects across phenotypes but showed significant effects specifically in patients classified as insulin resistant [16]. However, additional studies $[17,18]$ reported no beneficial effect of $\mathrm{Cr}$ supplementation for patients with metabolic syndrome, impaired glucose tolerance, or type 2 diabetes. Thus, the studies investigating the beneficial effects of chromium supplementation are still controversial and observed are restricted to very specific health compromised individuals. No beneficial pharmacologic effects have been documented in normal healthy individuals.

The basic biochemistry of $\mathrm{Cr}$ (III) has been well described. Studies in cell free systems $[19,20]$ characterized Cr(III)'s role in showing that it binds to DNA leading to a decrease in the fidelity and an increase in the processivity of DNA polymerases which may ultimately lead to increased mutations. A review of $\mathrm{Cr}$ (III) effects in cell-free systems shows positive results for a variety genotoxic outcomes including increased mutations [14]. Although $\mathrm{Cr}(\mathrm{III})$ is likely the ultimate reactant with DNA, the absorption of $\mathrm{Cr}$ (III) across the cell membrane is poor, and thus, studies in cell culture are difficult. Most of these studies have been conducted with less active inorganic salts which are poorly absorbed and require nonrelevant treatment concentrations. In addition, studies considering the effect of inorganic $\mathrm{Cr}(\mathrm{III})$ in vivo are largely negative with regard to genotoxic outcomes [14]. Studies of tannery workers with long term exposures to inorganic chromium do show evidence of genotoxic effects including chromosomal aberrations, micronuclei formation and DNA breaks [21-23]. Additionally, epidemiology studies have shown that workers exposed to inorganic $\mathrm{Cr}$ (III) have an increased potential risk for developing cancer [24]. These studies suggest that long term exposure is key in the contribution of $\mathrm{Cr}$ (III)-induced genotoxicity. In a more recent study, the long term effects of physiologically relevant concentrations of $\mathrm{Cr}$ (III) exposure in patients with CoCr hip implants were considered [25]. In this study, fibroblast cells were treated with levels of chromium equivalent to those measured in patients with both well functioning and worn implants and measured over time for chromosome stability. $\mathrm{Cr}$ (III) treated cells exhibited both numerical and structural chromosome instability. Indeed numerical and structural chromosome instability has recently been proposed as a novel mechanism for metal-induced carcinogenesis [26,27].

With the development of more bioavailable forms of $\mathrm{Cr}$ (III), such as chromium picolinate and chromium nicotinate, widely used in nutritional and pharmacological applications, the potential for toxicity has needed to be revisited. Cell culture studies have shown that $\mathrm{Cr}$ picolinate is able to damage DNA [28, 29], cause chromosomal aberrations [30], and induce mutations $[31,32]$ at physiologically relevant doses. One study was negative for induction of chromosome damage by $\mathrm{Cr}$ picolinate, however, treatment times were limited to only 4 hours [33]. A study investigating the metabolic fate of $\mathrm{Cr}$ (III) organic complexes suggests that high levels of intracellular $\mathrm{Cr}$ (III) can accumulate [34] leading to the formation of $\mathrm{Cr}$ DNA adducts and potentially causing genotoxic effects. In addition, recent developments in the ability to detect chemical speciation in biological media have revealed that many $\mathrm{Cr}$ (III) 
compounds can be oxidized in extracellular fluids leading to more efficient cellular uptake and DNA damage [35]. Animal studies provide further insight into the potential damage that $\mathrm{Cr}$ (III) may cause to the genome. The NTP (National Toxicology Program) recently reported equivocal findings of carcinogenicity in a 2 year rat and mice study of $\mathrm{Cr}$ picolinate, with adrenal cancers developing in male rats [36]. One study reported no chromosome damage found in bone marrow of rats treated with chromium picolinate; however, this was in a single $24 \mathrm{~h}$ oral exposure tested after 18 and $42 \mathrm{~h}$ [37]. There are no long term studies of organic $\mathrm{Cr}(\mathrm{III})$ that are comparable to the worker studies of inorganic $\mathrm{Cr}(\mathrm{III})$; the human studies of $\mathrm{Cr}$ (III) supplementation are focused on effects of glucose metabolism and do not measure genotoxicity. Overall the more bioavailable forms of $\mathrm{Cr}$ (III) have the potential to produce reactive oxygen species which can have profound consequences on its ability to react with DNA causing mutations and chromosome breakage leading to genomic instability and potentially carcinogenic effects [35,38].

While the field of $\mathrm{Cr}$ (III) research is wrought with controversy with respect to both its essentiality and its toxicity, there is no evidence of a role for $\mathrm{Cr}$ (III) with respect to maintaining genomic stability. Though all of the $\mathrm{Cr}$ (III) studies are heavily criticized by opposing viewpoints, from the studies investigated to date, $\mathrm{Cr}$ (III) does not play a role in DNA repair or its synthesis and it does not aid in free radical scavenging similar to other trace metals, such as zinc and copper.

\section{Chromium (VI)}

Hexavalent chromium has long been known to be a human respiratory carcinogen. The mechanisms for how chromium induces cancer are still being elucidated. The traditional view is that $\mathrm{Cr}(\mathrm{VI})$ acts by inducing mutations in the DNA sequence. This view is largely based on mammalian cell culture studies. For example, numerous studies used a shuttlevector mutagenesis system [39-42]. This system involved treating an SV-40 based plasmid in a cell-free system and then transfecting the damaged plasmid into cells. These studies report an increase in mutations after exposure to $10-200 \mathrm{uM}$ soluble $\mathrm{Cr}(\mathrm{VI})$.

Other cell culture studies considered mutagenesis with all components inside cells including systems with reporter genes (e.g. the bacterial gpt reporter gene) or an endogenous locus (e.g. the hprt locus) [43-45]. These studies also found an increase in mutagenesis though the toxicity of the doses used were high and the mutation frequency was low (i.e. $0-3.5 \%$ ). The one exception was a study that preloaded cells with $1.4 \mathrm{mM}$ ascorbate and found a 19.2-fold increase after exposure to $40 \mathrm{uM} \mathrm{Cr}(\mathrm{VI})$ and no mutations without ascorbate. These data suggest that ascorbate levels may be an important factor for $\mathrm{Cr}(\mathrm{VI})$-induced mutagenesis.

The $\mathrm{Cr}(\mathrm{VI})$-ascorbate studies argue that physiologically relevant levels of ascorbate are typically greater than $1 \mathrm{mM}$ and, thus, one needs to supplement with ascorbate to address this factor $[41,42,44]$. However, while $\mathrm{mM}$ ascorbate levels are consistent with levels found in freshly purified human lymphocytes [44], they are dramatically higher than those seen in human lung tissue. Specifically, two studies show that in adults, lung tissue ascorbate levels range from $0.045-0.065 \mathrm{mg} / \mathrm{g}$ which is approximately $256-369 \mathrm{uM}$ ascorbate [46]. A second study reported a range of $2.91-62.35 \mathrm{mg} / 100 \mathrm{~g}$ [47]. This measure can be converted 
to a range of $165 \mathrm{uM}$ to $3.5 \mathrm{mM}$. Recent data show that the methods used by these authors tend to overestimate ascorbate levels by a factor of 3 so that these ranges are more accurately $55 \mathrm{uM}-1.2 \mathrm{mM}$. Thus, it would appear that $1.4 \mathrm{mM}$ is above the normal range making it unclear how much of an issue ascorbate is. It is also notable that the study of ascorbate found no mutations at the hprt locus in hamster cells when ascorbate was absent, while another study did find mutations in the absence of ascorbate in this system indicating significant interlaboratory variation in results.

One study considered Cr(VI) mutagenesis in the Big Blue transgenic mouse [48]. Mice were exposed via intratracheal instillation and showed an increased mutation frequency in the lung. The challenge in interpreting these data are that no measures of inflammation in these animals were taken and $\mathrm{Cr}(\mathrm{VI})$ is a known irritant. Thus, it is unclear if the mutations are due to $\mathrm{Cr}(\mathrm{VI})$ directly or secondary to $\mathrm{Cr}(\mathrm{VI})$-induced inflammation

Considered together, one could argue that $\mathrm{Cr}(\mathrm{VI})$ induces mutations. On the other hand, the data also suggest that such events occur only under conditions of high dose, high toxicity or experimentally contrived systems such as the shuttle vector approach. Interestingly, the data for $\mathrm{Cr}(\mathrm{VI})$-induced tumors in workers show few mutations further supporting a conclusion that $\mathrm{Cr}(\mathrm{VI})$ is only weakly or indirectly mutagenic.

A newer mechanism that has been proposed lies in the ability of chromium to destabilize the genome [49]. Major causes of genomic instability include the induction of microsatellite instability, defective DNA repair, and the induction of both structural and numerical chromosome defects. Here, we discuss the mechanism of genomic instability with respect to chromium in order to emphasize the fact that chromium promotes genomic instability as opposed to providing protection.

Genomic instability is a common event in lung cancers with both microsatellite instability (MIN) and chromosome instability (CIN) occurring simultaneously. As reviewed by Holmes et al [49], Cr(VI)-induced tumors are no exception and are characterized by both MIN and CIN. MIN and reduced expression of both hMLH1 and hMLH2, key mismatch repair (MMR) genes, were reported in $\mathrm{Cr}(\mathrm{VI})$-induced tumors [50]. However, MIN is considered to occur in cells when they are deficient in MMR. Thus, MIN may play a role in the development of tumors but, only after MMR deficiency has developed. Thus, it is currently unclear if MIN is a driving factor or a consequence of other changes in the genome.

CIN includes both structural and numerical chromosome abnormalities. CIN has been reported in $\mathrm{Cr}(\mathrm{VI})$-induced tumors evidenced by an increase in the loss of heterozygosity consistent with cell culture studies that show a profound and consistent effect on chromosome structure in cultured cells treated with $\mathrm{Cr}(\mathrm{VI})$ [49]. Numerical abnormalities, have not been assessed in $\mathrm{Cr}(\mathrm{VI})$-induced tumors, but, multiple studies show that $\mathrm{Cr}(\mathrm{VI})$ dramatically alters chromosome number in cultured cells treated with $\mathrm{Cr}(\mathrm{VI})$ [26].

Epidemiology, animal and cell culture studies show that the particulate form of chromate is most potent with regards to carcinogenicity [51,52]. A mechanism for particulate $\mathrm{Cr}(\mathrm{VI})$ induced CIN has been proposed and supported [49]. Once the particle dissolves, the ability of $\mathrm{Cr}(\mathrm{VI})$ to cross the cell membrane using channel proteins aids in its rapid transport into 
the cell [52-55]. Once $\mathrm{Cr}(\mathrm{VI})$ enters the cell, it is rapidly reduced to $\mathrm{Cr}(\mathrm{III})$ which forms stable complexes with intracellular structures and accumulates within the cell [8]. It is able to form DNA adduct-based lesions, which lead to stalled replication forks and ultimately double strand breaks [39-42,44,45]. These DSBs overwhelm the repair systems of the cells which then go unrepaired or are mis-repaired leading to translocations and other structural aberrations [56,57]. The accumulation of DSBs also causes a G2 arrest leading to centrosome amplification and spindle assembly checkpoint bypass which lead to aneuploidy $[58,59]$.

In addition to the occupational studies of chromate workers, recent studies of patients with cobalt-chromium metal on metal hip implants have shown increases in CIN measured in their peripheral blood but the consequences of this are unknown [60]. To better understand the impact that chromium may have on these results, Figgett et al [25] investigated the effects of physiologically relevant metal levels on fibroblast cells. They found that cells treated with these physiological concentrations of $\mathrm{Cr}(\mathrm{VI})$ induced both structural and numerical chromosome aberrations, including complex aneuploidy.

NTP studies of rats and mice have revealed that long term oral exposure to $\mathrm{Cr}(\mathrm{VI})$ leads to higher accumulation in multiple tissues [61]. These long term exposures of $\mathrm{Cr}(\mathrm{VI})$ lead to the development of intestinal tumors in mice and in the oral mucosa of rats $[62,63]$. In addition, a recent epidemiologic study implicated $\mathrm{Cr}(\mathrm{VI})$ in drinking water as the cause of liver, lung and urologic cancers [64]. However, the mode of action is unclear for these novel $\mathrm{Cr}(\mathrm{VI})$-induced cancers and more research needs to be done in these specific tissue and cell types [65]. There have also been no investigations performed to determine direct effects on DNA or chromosome status in these tumors.

$\mathrm{Cr}(\mathrm{VI})$-induced DNA damage is repaired by several mechanism depending on the type of damage incurred. Base excision repair, single strand break repair, nucleotide excision repair, mismatch repair, homologous recombination, and crosslink repair have all been studied in the repair of $\mathrm{Cr}(\mathrm{VI})$-induced DNA damage as reviewed in Wise et al [7]. All of the lesions, if unrepaired or mis-repaired, can directly impact chromosome structure and overall genomic integrity leading to carcinogenesis.

\section{Conclusion}

As outlined above, metals can have crucial roles in the maintenance of the genome. These roles include antioxidant and free radical scavenging agents, DNA synthesis and repair processes. None of these roles have been elucidated with respect to chromium. In fact, as reviewed here, both $\mathrm{Cr}(\mathrm{III})$ and $\mathrm{Cr}(\mathrm{VI})$ have shown evidence for quite the opposite. Both $\mathrm{Cr}(\mathrm{III})$ and $\mathrm{Cr}(\mathrm{VI})$ have been shown to damage DNA and break chromosomes which can lead to genome instability and cancer.

\section{Acknowledgments}

We also thank Christy Gianios, Jr. for IT support. This work was supported by NIEHS grant\# 1R01ES016893-01A1, and NASA grant numbers ACD FSB-2009, and EP-09-05 (all three to J.P.W.), the Maine Center for Toxicology and Environmental Health, and the Department of Applied Medical Sciences, University of Southern Maine, Portland ME. 


\section{References}

1. Cahill DP, Kinzler KW, Vogelstein B, Lengauer C. Genetic instability and Darwinian selection in tumours. Trends Cell Biol. 1999; 9:M57-M60. [PubMed: 10611684]

2. Michor F, Iwasa Y, Vogelstein B, Lengauer C, Nowak MA. Can chromosomal instability initiate tumorigenesis? Semin Cancer Biol. 2005; 15:43-49. [PubMed: 15613287]

3. Fenech M, Ferguson L. Vitamins/minerals and genomic stability in humans. Mutat Res. 2001; 475:1-6. [PubMed: 11295148]

4. Hartwig A. The role of magnesium in genomic instability. Mutat Res. 2001; 475:113-121. [PubMed: 11295157]

5. Linder M. Copper and genomic stability in mammals. Mutat Res. 2001; 475:141-152. [PubMed: 11295159]

6. Cheng W-H. Impact of Inorganic Nutrients on Maintenance of Genomic Stability. Environ Mol Mutagen. 2009; 50:349-360. [PubMed: 19326466]

7. Wise SS, Holmes AL, Wise JP Sr. Hexavalent Chromium-Induced DNA Damage and Repair Mechanisms. Rev Environ Health. 2008; 23:39-57. [PubMed: 18557597]

8. De Flora S, Wetterhahn KE. Mechanisms of chromium metabolism and genotoxicity. Life Chem Rep. 1989; 7:169-244.

9. Cohen MD, Kargacin B, Klein CB, Costa M. Mechanisms of chromium carcinogenicity and toxicity. Crit Rev Toxicol. 1993; 23:255-281. [PubMed: 8260068]

10. O'Brien TJ, Ceryak S, Patierno SR. Complexities of chromium carcinogenesis: role of cellular response, repair and recovery mechanisms. Mutat Res. 2003; 533:3-36. [PubMed: 14643411]

11. Nielson, F. The clinical and nutritional importance of chromium - Still debated after 50 years of research. In: Vincent, JB., editor. The Nutritional Biochemistry of Chromium (III). Elsevier; Amsterdam: 2007. p. 265-276.

12. Vincent, JB.; Stallings, D. A history of chromium studies (1955-1995). In: Vincent, JB., editor. The Nutritional Biochemistry of Chromium (III). Elsevier; Amsterdam: 2007. p. 1-40.

13. Stearns, D. Multiple hypotheses for chromium (III) biochemistry: Why the essentiality of chromium (III) is still questioned. In: Vincent, JB., editor. The Nutritional Biochemistry of Chromium (III). Elsevier; Amsterdam: 2007. p. 57-70.

14. Eastmond DA, MacGregor JT, Slesinski RS. Trivalent Chromium: Assessing the Genotoxic Risk of an Essential Trace Element and Widely Used Human and Animal Nutritional Supplement. Critical Rev in Toxicol. 2008; 38:173-190. [PubMed: 18324515]

15. Balk EM, Tatsioni A, Lichtenstein AH, Lau J, Pittas AG. Effect of chromium supplementation on glucose metabolism and lipids: a systematic review of randomized controlled trials. Diabetes Care. 2007; 30:2154-2163. [PubMed: 17519436]

16. Cefalua WT, Rooda J, Pinsonata P, Qina J, Seredaa O, Levitana L, Andersonb RA, Zhanga XH, Martinc JM, Martina CK, Wanga ZQ, Newcomer B. Characterization of the metabolic and physiologic response from chromium supplementation in subjects with type 2 diabetes. Metabolism. 2010; 59:755-762. [PubMed: 20022616]

17. Gunton JE, Cheung NW, Hitchman R, Hams G, O’Sullivan C, Foster-Powell K, McElduff A. Chromium supplementation does not improve glucose tolerance, insulin sensitivity, or lipid profile: a randomized, placebo-controlled, double-blind trial of supplementation in subjects with impaired glucose tolerance. Diabetes Care. 2005; 28:712-713. [PubMed: 15735214]

18. Iqbal N, Cardillo S, Volger S, Bloedon LT, Anderson RA, Boston R, Szapary PO. Chromium picolinate does not improve key features of metabolic syndrome in obese non-diabetic adults. Metab Syndr Relat Disord. 2009; 7:143-150. [PubMed: 19422140]

19. Snow E. A possible role for chromium (III) in genotoxicity. Environ Health Perspect. 1991; 92:7581. [PubMed: 1935855]

20. Snow E, Xu L. Chromium(III) bound to DNA templates promotes increased polymerase processivity and decreased fidelity during replication in vitro. Biochemistry. 1991; 30:1123811245. [PubMed: 1958661] 
21. Sbrana I, Caretto S, Lascialfari D, Rossi G, Marchi M, Loprieno N. Chromosomal monitoring of chromium-exposed workers. Mutat Res. 1990; 242:305-12. [PubMed: 2255324]

22. Medeiros MG, Rodrigues AS, Batoreu MC, Laires A, Rueff J, Zhitkovich A. Elevated levels of DNA-protein crosslinks and micronuclei in peripheral lymphocytes of tannery workers exposed to trivalent chromium. Mutagenesis. 2003; 18:19-24. [PubMed: 12473731]

23. Meibiana Z, Zhijian C, Qing C, Hua Z, Jianlin L, Jiliang H. Investigating DNA damage in tannery workers occupationally exposed to trivalent chromium using comet assay. Mutat Res. 2008; 654:45-51. [PubMed: 18541454]

24. Mancuso TF. Chromium as an industrial carcinogen: Part 1. Am J Ind Med. 1997; 31:129-139. [PubMed: 9028428]

25. Figgitt M, Newson R, Leslie IJ, Fisher J, Ingham E, Case CP. The genotoxicity of physiological concentrations of chromium $(\mathrm{Cr}(\mathrm{III})$ and $\mathrm{Cr}(\mathrm{VI}))$ and cobalt $(\mathrm{Co}(\mathrm{II}))$ : An in vitro study. Mutat Res. 2010; 688:53-61. [PubMed: 20227425]

26. Wise SS, Wise JP Sr. Aneuploidy as an Early Mechanistic Event in Metal Carcinogenesis. Biochemical Society Transactions. 2010; 38:1650-1654. [PubMed: 21118142]

27. Holmes AL, Wise JP Sr. Mechanisms of Metal-Induced Centrosome Amplification. Biochemical Society Transactions. 2010; 38:1687-1690. [PubMed: 21118148]

28. Bagchi D, Stohs SJ, Downs BW, Bagchi M, Preuss HG. Cytotoxicity and oxidative mechanisms of different forms of chromium. Toxicology. 2002; 180:5-22. [PubMed: 12324196]

29. Andersson MA, Peterson Grawe KV, Karlsson OM, Abramsson-Zetterberg LAG, Hellman BE. Evaluation of the potential genotoxicity of chromium picolinate in mammalian cells in vivo and in vitro. Food Chem Toxicol. 2007; 45:1097-1106. [PubMed: 17418471]

30. Stearns DM, Wise JP Sr, Patierno SR, Wetterhahn KE. Chromium(III) picolinate produces chromosome damage in Chinese hamster ovary cells. Faseb J. 1995; 9:1643-1648. [PubMed: 8529845]

31. Stearns DM, Silveira SM, Wolf KK, Luke AM. Chromium(III) tris(picolinate) is mutagenic at the hypoxanthine (guanine) phosphoribosyltransferase locus in Chinese hamster ovary cells. Mutat Res. 2002; 513:135-142. [PubMed: 11719098]

32. Coryell VH, Stearns DM. Molecular analysis of hprt mutations induced by chromium picolinate inCHOAA8 cells. Mutat Res. 2006; 610:114-123. [PubMed: 16877033]

33. Gudi R, Slesinski RS, Clarke JJ, San RH. Chromium picolinate does not produce chromosome damage in CHO cells. Mutat Res. 2005; 587:140-146. [PubMed: 16216543]

34. Kareus SA, Kelley C, Walton HS, Sinclair PR. Release of Cr(III) from Cr(III) picolinate upon metabolic activation. J Hazard Mater. 2001; 84:163-174. [PubMed: 11406304]

35. Levina A, Lay PA. Chemical Properties and Toxicity of Chromium(III) Nutritional Supplements. Chem Res Toxicol. 2008; 21:563-571. [PubMed: 18237145]

36. Stout MD, Nyska A, Collins BJ, Witt KL, Kissling GE, Malarkey DE, Hooth MJ. Chronic Toxicity and Carcinogenicity Studies of Chromium Picolinate Monohydrate Administered in Feed to F344/N Rats and B6C3F1 Mice for 2 Years. Food Chem Toxicol. 2009; 47:729-733. [PubMed: 19166900]

37. Komorowski JR, Greenberg D, Juturu V. Chromium picolinate does not produce chromosome damage. Toxicol in Vitro. 2008; 22:819-826. [PubMed: 18261879]

38. Ke, Q.; Costa, M. Overview of chromium (III) toxicology. In: Vincent, JB., editor. The Nutritional Biochemistry of Chromium (III). Elsevier; Amsterdam: 2007. p. 257-263.

39. Zhitkovich A, Song Y, Quievryn G, Voitkun V. Non-oxidative mechanisms are responsible for the induction of mutagenesis by reduction of $\mathrm{Cr}(\mathrm{VI})$ with cysteine: Role of ternary DNA adducts in Cr(III)-dependent mutagenesis. Biochemistry. 2001; 40:549-560. [PubMed: 11148050]

40. Zhitkovich A, Quievryn G, Messer J, Motylevich Z. Reductive activation with cysteine represents a chromium(III)-dependent pathway in the induction of genotoxicity by carcinogenic chromium(VI). Environ Health Perspect. 2002; 110:729-731. [PubMed: 12426121]

41. Quievryn G, Peterson E, Messer J, Zhitkovich A. Genotoxicity and mutagenicity of chromium(VI)/ ascorbate-generated DNA adducts in human and bacterial cells. Biochemistry. 2003; 42:10621070. [PubMed: 12549927] 
42. Quievryn G, Messer J, Zhitkovich A. Lower mutagenicity but higher stability of Cr-DNA adducts formed during gradual chromate activation with ascorbate. Carcinogenesis. 2006; 27:2316-2321. [PubMed: 16714765]

43. Klein CB, Su L, Bowser D, Leszczynska J. Chromate-induced epimutations in mammalian cells. Environ Health Perspect. 2002; 110:739-43. [PubMed: 12426123]

44. Reynolds M, Stoddard L, Bespalov I, Zhitkovich A. Ascorbate acts as a highly potent inducer of chromate mutagenesis and clastogenesis: linkage to DNA breaks in G2 phase by mismatch Repair. Nucleic Acids Res. 2007; 35:465-476. [PubMed: 17169990]

45. Brooks B, O’Brien TJ, Ceryak S, Wise JP Sr, Wise SS, Wise JP Jr, DeFabo E, Patierno SR. Excision repair is required for genotoxin-induced mutagenesis in mammalian cells. Carcinogenesis. 2008; 29:1064-1069. [PubMed: 18332048]

46. Yavorsky M, Almaden P, King CG. The vitamin C content of human tissues. J Biol Chem. 1934; 106:525-529.

47. Slade R, Stead AG, Graham JA, Hatch GE. Comparison of lung antioxidant levels in humans and laboratory animals. Am Rev Respir Dis. 1985; 131:742-746. [PubMed: 4003918]

48. Cheng L, Sonntag DM, de Boer J, Dixon K. Chromium(VI)-induced mutagenesis in the lungs of big blue transgenic mice. J Environ Pathol Toxicol Oncol. 2000; 19:239-49. [PubMed: 10983890]

49. Holmes AL, Wise SS, Wise JP Sr. Carcinogenicity of hexavalent chromium. Indian J Med Res. 2008; 128:353-372. [PubMed: 19106434]

50. Hirose T, Kondo K, Takahashi Y, Ishikura H, Fujino H, Tsuyuguchi M, Hashimoto M, Yokose T, Mukai K, Kodama T, Monden Y. Frequent microsatellite instability in lung cancer from chromateexposed workers. Mol Carcin. 2002; 33:172-80.

51. IARC Monographs on the Evaluation of Carcinogenic Risks to Humans: Chromium, Nickel and Welding. Vol. 49. International Agency for Research on Cancer; Lyons, France: 1990.

52. Leonard A, Lauwerys RR. Carcinogenicity and mutagenicity of chromium. Mutat Res. 1980; 76:227-239. [PubMed: 7010127]

53. Levy LS, Vanitt S. Carcinogenicity and mutagenicity of chromium compounds: the association between bronchial metaplasia and neoplasia. Carcinogenesis. 1986; 7:831-835. [PubMed: 3698209]

54. Patierno SR, Banh D, Landolph JR. Transformation of C3H/10T1/2 mouse embryo cells by insoluble lead chromate but not soluble calcium chromate: relationship to mutagenesis and internalization of lead chromate particles. Cancer Res. 1988; 47:3815-3823.

55. Langard S. One hundred years of chromium and cancer: A review of epidemiological evidence and selected case reports. Am J Ind Med. 1990; 17:189-215. [PubMed: 2405656]

56. Xie H, Holmes AL, Wise SS, Huang S, Peng C, Wise JP Sr. Neoplastic transformation of human bronchial cells by lead chromate particles. Am J Respir Cell Mol Biol. 2007; 37:544-552. [PubMed: 17585109]

57. Xie H, Wise SS, Wise JP Sr. Deficient repair of particulate chromate-induced DNA double strand breaks leads to neoplastic transformation. Mutat Res. 2008; 649:230-238. [PubMed: 18023605]

58. Holmes AL, Wise SS, Sandwick SJ, Lingle WL, Negron VC, Thompson WD, Wise JP Sr. Chronic exposure to lead chromate causes centrosome abnormalities and aneuploidy in human lung cells. Cancer Res. 2006; 66:4041-4048. [PubMed: 16618723]

59. Wise SS, Holmes AL, Xie H, Thompson WD, Wise JP Sr. Chronic exposure to particulate chromate induces spindle assembly checkpoint bypass in human lung cells. Chem Res Toxicol. 2006; 19:1492-1498. [PubMed: 17112237]

60. Dunstan E, Ladon D, Whittingham-Jones P, Carrington R, Briggs TWR. Chromosomal Aberrations in the Peripheral Blood of Patients with Metal-on-Metal Hip Bearings. J Bone and Joint Surgery. 2008; 90-A:517-522.

61. Collins BJ, Stout MD, Levine KE, Kissling GE, Melnick RL, Fennell TR, Walden R, Abdo K, Pritchard JB, Fernando RA, Burka LT, Hooth MJ. Exposure to hexavalent chromium resulted in significantly higher tissue chromium burden compared to trivalent chromium following similar oral doses to male F344/n rats and female B6C3F1 mice. Toxicol Sci. 2010; 118:368-379.

[PubMed: 20843897] 
62. National Toxicology Program (NTP). National Toxicology Program. Research Triangle Park, NC: 2008. Toxicology and Carcinogenesis Studies of Sodium Dichromate Dihydrate (CAS No. 7789-12-0) in F344/N Rats and B6C3F1 Mice Drinking Water Studies.

63. Stout MD, Herbert RA, Kissling GE, Collins BJ, Travlos GS, Witt KL, Melnick RL, Abdo KM, Malarkey DE, Hooth MJ. Hexavalent chromium is carcinogenic to F344/N rats and B6C3F1 mice after chronic oral exposure. Environ Health Perspect. 2009; 117:716-722. [PubMed: 19479012]

64. Linos A, Petralias A, Christophi CA, Christoforidou E, Kouroutou P, Stoltidis M, Veloudaki A, Tzala E, Makris KC, Karagas MR. Oral ingestion of Hexavalent chromium through drinking water and cancer mortality in an industrial area of Greece - An ecological study. Environ Health. 2011; 10 Published online 2011 May 24. 10.1186/1476-069X-10-50

65. Thompson CM, Haws LC, Harris MA, Gatto NM, Proctor DM. Application of the U.S. EPA Mode of Action Framework for Purposes of Guiding Future Research: A Case Study Involving the Oral Carcinogenicity of Hexavalent Chromium. Tox Sci. 2011; 119:20-40. 